DOI: http://dx.doi.org/10.35137/jabk.v6i3.324

\title{
ANALISIS PENGARUH PENDAPATAN MARGIN MURABAHAH DAN PENDAPATAN BAGI HASIL MUSYARAKAH TERHADAP LABA BERSIH PT BANK NEGARA INDONESIA SYARIAH (Periode Tahun 2012 - 2018)
}

\author{
Eva Nuraisyah ${ }^{1}$ \\ Program Studi Akuntasi Fakultas Ekonomi \\ Universitas Krisnadwipayana \\ Herry Winarto ${ }^{2}$ \\ Program Studi Akuntasi Fakultas Ekonomi \\ Universitas Krisnadwipayana \\ herrywinarto45@yahoo.com
}

\begin{abstract}
This type of research uses quantitative research. The data source used in this study is secondary data. Data analysis method used is hypothesis testing, namely the $t$ test and $f$ test. The results of this study indicate that Murabahak Margin Income and Musyarakah Profit Sharing Revenue simultaneously have a significant effect on Net Profit of Murabahak Margin Income partially, and Musyarakah Revenue Sharing has a significant influence, PT Bank Negara Indonesia Tbk. To obtain data, researchers used the website of PT Bank Negara Indonesia Tbk, and the Indonesia Stock Exchange (IDX). By conducting research on financial data for the period 2012-2018 analyzed using SPSS 25.0
\end{abstract}

Keywords: Murabahah Margin Income, Musyarakah Profit Sharing Income and Net Profit

\section{PENDAHULUAN}

Pada kehidupan zaman sekarang tidak dapat lepas dengan dunia ekonomi, ada banyak segi yang dapat dilihat dar isisi ekonomi, salah satunya dikenal dengan kegiatan perbankkan yang digunakan oleh masyarakat. Perbankkan sangat mempengaruhi kegiatan perekonomian suatu negara. Hubungan antara masyarakat dan perbankkan hampir sulit untuk dipisahkan, terlebih pada dunia yang modern pada saat ini.Pada Juli 1997 perbankkan Indonesia pernah mengalami krisis moneter yang melanda dunia dan disusul dengan krisis politik nasional yang telah membawa dampak besar bagi perekonomian di Indonesia. Krisis tersebut menyebabkan dampak pada perbankkan Indonesia saat ini, yang didominasi oleh bank konvensional mengalami kesulitan penggunaan bunga, meskipun awalnya mampu mendorong bergeraknya sektor perbankkan secara dinamis, namun telah menjadikan perekonomian Indonesia mengalami efek pertumbuhan semu yang menyebabkan beberapa bank konvensional akhirnya kritis dan tidaklayak beroperasi. Keadaan tersebut menyebabkan pemerintah Indonesia terpaksa mengambil tindakan untuk rekonstrukturisasi sebagian bank di Indonesia. Salah satu tindakan pemerintah adalah melakukan perubahanan undang - undang perbankkan dengan disahkannya Undang-Undang No. 10 tahun 1998 sebagai perubahan UndangUndang No. 7 tahun 1992 tentang perbankan telah memberi kesempatan luas untuk pengembangan jaringan perbankan syariah telah menyadarkan semua pihak bahwa perbankkan dengan sistem konvensional bukan merupakan satu-satunya sistem yang dapat diandalkan, karena ada sistem perbankkan lain yang lebih unggul dengan menawarkan prinsip keadilan dan keterbukaaan, yaitu perbankkan syariah. (Kurniasari, Cahyono dan Yulinartati, 2015).

Berdasarkan Undang - Undang Nomor 21 Tahun 2008 tentang Perbankkan Syariah, bank Syariah dikembangkan dengan tujuan meningkatkan kesejahteraan, pemerataan, dan pertumbuhan ekonomi nasional melalui berbagai layanan perbankan seperti simpan pinjam dan investasi berdasarkan prinsip dan hukum Islam. Sementara pada bulan Agustus 
DOI: http://dx.doi.org/10.35137/jabk.v6i3.324

2016 statistik perbankkan syariah menunjukkan bahwa telah berdiri 165 Bank Pembiayaan Rakyat Syariah dengan 436 kantor, dan 13 Bank Umum Syariahdengan 1869 kantor. (Agza dan Darwanto, 2017).

Bank Negara Indonesia (BNI) dari tahun ke tahun selalu menunjukkan kekuatannya dalam industri perbankkan dan kepercayaan masyarakat sebagai pilihan tempat penyimpanan suatu kekayaan yang terpercaya. Permintaan akan perbankkan yang sesuai dengan prinsip syariah mulai bermunculan yang pada akhirnya BNI membuka layanan perbankan yang sesuai dengan prinsip syariah dengan konsep dual system banking, yaitu menyediakan layanan perbankkan umum dan syariah sekaligus. Hal ini sesuai dengan UU No. 10 Tahun 1998 memungkinkan bank-bank umum untuk membuka layanan syariah, diawali dengan pembentukan Tim Bank Syariah di Tahun 1999, Bank Indonesia kemudian mengeluarkan ijin prinsip dan usaha untuk beroperasinya unit usaha syariah BNI. Setelah itu BNI Syariah menerapkan strategi pengembangan jaringan cabang syariah, tepatnya pada tanggal 29 April 2000 BNI Syariah membuka 5 kantor cabang syariah sekaligus di kota-kota potensial, yaitu Yogyakarta, Malang, Pekalongan, Jepara dan Banjarmasin. Tahun 2001 BNI Syariah kembali membuka 5 kantor cabang syariah yang difokuskan ke kota-kota besar di Indonesia, yaitu Jakarta (2 cabang), Bandung, Makassar, dan Padang. Tahun 2002 lalu BNI Syariah membuka dua kantor cabang syariah baru di Medan dan Palembang, kemudian pada awal tahun 2003 pertimbangan bisnis yang semakin meningkat sehingga untuk meningkatkan pelayanan kepada masyarakat, BNI Syariah melakukan relokasi kantor cabang syariah dari Jepara ke Semarang. Sedangkan untuk melayani masyarakat kota Jepara BNI Syariah membuka Kantor Cabang, Cabang Pembantu Syariah Jepara. Pada bulan Agustus dan September 2004, BNI Syariah membuka layanan BNI Syariah Prima di Jakarta dan Surabaya layanan ini diperuntukkan untuk individu yang membutuhkan layanan perbankkan yang lebih personal dalam suasana yang nyaman. Sehingga dari awal beroperasi hingga kini, BNI Syariah menunjukkan pertumbuhan yang signifikan disamping itu komitmen Pemerintah terhadap pengembangan perbankan syariah semakin kuat dan kesadaran terhadap keunggulan produk perbankkan syariah juga semakin meningkat.

Lembaga keuangan syariah menunjukkan popularitasnya dengan melakukan penghimpunan dana dengan penentuan harga atau mencari keuntungan bagi bank syariah dengan cara pembiayaan berdasarkan pembiayaan berdasarkan prinsip penyertaan modal, prinsip bagi hasil, pembiayaan barang modal berdasarkan sewa tanpa pilihan, prinsip jual beli barang dengan memperoleh keuntungan, dan pemindahan kepemilikan atas barang yang disewa dari pihak bank oleh pihak lain. Prinsip jual beli yang banyak digunakan salah satunya adalah pembiayaan murabahah. Pembiayaan murabahah penjualan barang dengan menyatakan perolehan dan harga keuntungan yang disepakati oleh penjual (bank) dan pembeli (nasabah), pembayaran dapat dilakukan secara tunai maupun tangguh. Pendapatan kegiatan operasi bank syariah dalam bentuk pembiayaan murabahah merupakan pendapatan margin murabahah yaitu keuntungan yang ditetapkan bank atas transaksi pembiayaan jual beli murabahah, nasabah dapat mengangsur barang yang diperoleh dari pembiayaan murabahah. Margin murabahah bila sudah melakukan ijab kabul bersifat tetap, sehingga harga jual tidak boleh berubah. (Karlina, 2017).

Bentuk produk pembiayaan dengan prinsip bagi hasil yang ada pada banksyariah adalah pembiayaan musyarakah dan mudharabah, pembiayaan musyarakah baik bank maupun nasabah memberikan dana untuk modal kerja usaha, menyediakan dana untuk membiayai suatu proyek secara bersama bahwa keuntungan dibagi hasil berdasarkan kesepakatan sebelumnya sedangkan kerugian dibagi berdasarkan kontribusi dana. Musyarakah permanen adalah musyarakah dengan ketentuan bagian dana setiap mitra ditentukan sesuai akad dan jumlahnya tetap hingga akhir masa akad. Musyarakah menurun (musyarakah mutanaqisha) adalah musyarakah dengan ketentuan bagian dana salah satu mitra akan dialihkan secara bertahap kepada mitra lainnya sehingga bagian dananya akan menurun dan pada akhir masa akad mitra lain tersebut akan menjadi pemilik penuh 
DOI: http://dx.doi.org/10.35137/jabk.v6i3.324

usaha tersebut. Musyarakah dinyatakan sebesar saldo pembiayaan dikurangi dengan saldo penyisihan kerugian. Bank menetapkan penyisihan kerugian sesuai dengan kualitas pembiayaan berdasarkan pemilahan atas masing-masing saldo pembiayaan kemudian menghasilkan pendapatan bagi hasil musyarakah. (PSAK No 106). Tingginya tingkat pendapatan margin murabahah dan pendapatan bagi hasil musyarakah yang disalurkan secara efektif dan efisien akan menambah tingkat laba bersih. Modal laba bersih yang besar akan mampu menghadapi persaingan sekaligus melakukan ekspansi pasar. Usaha bank akan lebih terjangkau dengan meratanya tingkat pendapatan yang diperoleh setiap produk tersebut untuk mengoptimalkan perolehan laba.

Tujuan dari penelitian ini adalah untuk mendapatkan data dalam upaya untuk mengetahui pengaruh pendapatan murabahah dan musyarakah terhadap laba bersih pada Bank Negara Indonesia Syariah. Secara rinci tujuan tersebut adalah sebagai berikut: 1).Untuk mengetahui pengaruh secara parsial pendapatan margin murabahah terhadap laba bersih pada Bank Negara Indonesia Syariah, 2). Untuk mengetahui pengaruh secara parsial pendapatan bagi hasil musyarakah terhadap laba bersih pada Bank Negara Indonesia Syariah, 3.Untuk mengetahui pengaruh secara simultan pendapatan margin murabahah dan Pendapatan Bagi Hasil musyarakah terhadap laba bersih pada Bank Negara Indonesia Syariah.

\section{METODE PENELITIAN}

Dalam penelitian ini menggunakan metode penelitian dokumentasi, yaitu suatu penelitian yang dilakukan dengan cara mencatat atau mendokumentasikan data yang sudah ada. Pengumpulan data dimulai dengan tahap penelitian pendahulu yaitu dengan mempelajari buku, artikel dan jurnal maupun situs yang berhubungan dengan pokok bahasan dalam penelitian ini, dan dilakukan pengkajian data yang dibutuhkan, ketersediaan data, dan cara memperoleh data. Tahap berikutnya adalah mengumpulkan keseluruhan data yang dibutuhkan guna menjawab persoalan penelitian, memperbanyak literatur untuk menunjang data kuantitatif yang diperoleh.
Data dalam penelitian ini menggunakan data sekunder. Satuan analisis dalam penelitian ini adalah emiten Bank BNI 46 kosmetik dan rumah tangga. Data sekunder tersebut diperoleh dari Bursa Efek Indonesia dengan mengakses website www.idx.co.id

\section{HASIL DAN PEMBAHSAN \\ Analisis Korelasi.}

Untuk melihat dan mengetahui kekuatan hubungan antara variabel pendapatan margin murabahah dan pendapatan bagi hasil musyarakah dalam kaitannya dengan laba bersih. Dari hasil pengolahan data diketahui yaitu: Analisis Korelasi Parsial Pendapatan Margin Murabahah terhadap Laba Bersih. Koefisien korelasi parsial antara pendapatan margin murabahah terhadap laba bersih sebagai berikut:

Tabel 1.Koefisien KorelasiCorrelations

\begin{tabular}{|c|c|c|c|}
\hline & & $\begin{array}{l}\text { Pendapatan } \\
\text { Margin } \\
\text { Murabahah }\end{array}$ & $\begin{array}{l}\text { Laba } \\
\text { Bersih }\end{array}$ \\
\hline \multirow{3}{*}{$\begin{array}{l}\text { Pendapatan } \\
\text { Margin } \\
\text { Murabahah }\end{array}$} & $\begin{array}{l}\text { Pearson } \\
\text { Correlation }\end{array}$ & 1 &, $920(* *)$ \\
\hline & $\begin{array}{l}\text { Sig. } \\
\text { tailed) }\end{array}$ & &, 000 \\
\hline & & 7 & 7 \\
\hline \multirow[t]{3}{*}{ Laba Bersih } & $\begin{array}{l}\text { Pearson } \\
\text { Correlation }\end{array}$ &, $920(* *)$ & 1 \\
\hline & $\begin{array}{l}\text { Sig. } \\
\text { tailed })\end{array}$ & & \\
\hline & $\mathrm{N}$ & 7 & 7 \\
\hline
\end{tabular}

** Correlation is significant at the 0.01 level (1-tailed). Sumber : Data analisis statistik

Berdasarkan perhitungan dengan
menggunakan koefisien kolerasi perlu diinterprestasikan maknanya agar dapat diketahui hubungan antara pendapatan margin murabahah dengan laba bersih. Maka nilai koefisien korelasi antara pendapatan margin murabahah dengan laba bersih sebesar 0,920 dengan arah positif. Hal ini menunjukkan bahwa pendapatan margin murabahah dengan laba bersih menunjukkan hubungan yang sangat kuat karena berada diantara 0,80 1,000 yang berarti pendapatan margin murabahah sangat kuat dalam meningkatkan laba bersih. Analisis Korelasi Parsial Pendapatan Bagi Hasil Musyarakah terhadap Laba Bersih. Koefisien korelasi parsial antara pendapatan bagi hasil musyarakah terhadap laba bersih sebagai berikut: 
DOI: http://dx.doi.org/10.35137/jabk.v6i3.324

Tabel 2. Koefisien Korelasi Correlations

\begin{tabular}{|c|c|c|c|}
\hline & & $\begin{array}{l}\text { Pendapatan } \\
\text { Bagi Hasil } \\
\text { Musyarakah }\end{array}$ & $\begin{array}{l}\text { Laba } \\
\text { Bersih }\end{array}$ \\
\hline Pendapatan & Pearson & \multirow{3}{*}{1} & \multirow{2}{*}{, $970(* *)$} \\
\hline Bagi Hasil & Correlation & & \\
\hline Musyarakah & $\begin{array}{l}\text { Sig. } \\
\text { tailed) }\end{array}$ & & ,000 \\
\hline \multirow{4}{*}{ Laba Bersih } & $\mathrm{N}$ & 7 & 7 \\
\hline & Pearson &, $970(* *)$ & \\
\hline & Sig. (1- & ,000 & \\
\hline & $\mathrm{N}$ & 7 & 7 \\
\hline
\end{tabular}

** Correlation is significant at the 0.01 level (1-tailed). Sumber : Data analisis statistik

Berdasarkan perhitungan dengan menggunakan koefisien korelasi perlu diinterprestasikan maknanya agar dapat diketahui hubungan antara pendapatan bagi hasil musyarakah dengan laba bersih. Maka nilai koefisien korelasi antara pendapatan bagi hasil musyarakah dengan laba bersih sebesar 0,970 dengan arah positif. Hal ini menunjukkan bahwa pendapatan bagi hasil musyarakah dengan laba bersih menunjukkan hubungan yang sangat kuat karena berada diantara $0,80-1,000$ yang berarti apabila pendapatan bagi hasil musyarakah meningkat maka laba bersih juga meningkat begitu sebaliknya. Analisis Korelasi Berganda (Simultan) Pendapatan Margin Murabahah dan Pendapatan Bagi Hasil Musyarakah terhadap Laba Bersih. Analsisis korelasi berganda merupakan angka yang menunjukkan kekuatan hubungan antar kedua variabel bebas pendapatan margin murabahah dan pendapatan bagi hasil musyarakah secara bersama-sama atau simultan dengan variabel laba bersih. Hubungan korelasi secara bersama-sama atau simultan dapat dilihat pada tabel berikut:

Tabel 3. Analisis Korelasi Berganda Model Summary(b)

\begin{tabular}{|c|c|c|c|c|c|}
\hline $\begin{array}{l}\text { Mod } \\
\text { el }\end{array}$ & $\mathrm{R}$ & $\begin{array}{l}\text { R } \\
\text { Squar } \\
\mathrm{e}\end{array}$ & $\begin{array}{l}\text { Adjuste } \\
\mathrm{d} \quad \mathrm{R} \\
\text { Square }\end{array}$ & $\begin{array}{l}\text { Std. } \\
\text { Error } \\
\text { of the } \\
\text { Estima } \\
\text { te }\end{array}$ & $\begin{array}{l}\text { Durbi } \\
\mathrm{n}- \\
\text { Watso } \\
\mathrm{n}\end{array}$ \\
\hline 1 & $\begin{array}{l}\text {,995( } \\
\text { a) }\end{array}$ & ,990 & ,985 & $\begin{array}{l}853.21 \\
5\end{array}$ & 2,498 \\
\hline
\end{tabular}

a Predictors: (Constant), Pendapatan Bagi Hasil Musyarakah, Pendapatan Margin Murabahah b Dependent Variable: Laba Bersih

Sumber : Data analisis statistik

Berdasarkan perhitungan dengan menggunakan koefisien korelasi berganda perlu diinterprestasikan artinya agar dapat diketahui hubungan antara pendapatan margin murabahah dan pendapatan bagi hasil musyarakah dengan laba bersih secara bersama-sama sebagai dasar untuk menginterprestasikan pengaruh kedua variabel, digunakan pedoman interprestasi koefisien korelasi. Pada posisi hubungan antara pendapatan margin murabahah dan pendapatan bagi hasil musyarakah terhadap laba bersih secara simultan atau bersamasama, maka dapat dilihat dari tabel koefisien korelasi sebesar 0,995 yang artinya hubungan antara pembiayaan pendapatan margin murabahah dan pendapatan bagi hasil musyarakah terhadap laba bersih secara bersama-sama menunjukan hubungan yang sangat kuat karena berada diantara 0,80 1,000 yang berarti apabila pendapatan margin murabahah dan pendapatan bagi hasil musyarakah meningkat maka laba bersih juga meningkat begitu pula sebaliknya. Analisis Koefisien Determinasi.

Koefisien determinasi digunakan untuk melihat seberapa besar variabel antara pendapatan margin murabahah dan pendapatan bagi hasil musyarakah terhadap laba bersih secarabe rsama-sama. Untuk menilai koefisien determinasi dapat dilihat dari tabel IV.3 dilihat dari nilai $\mathrm{R}$ Square yaitu sebesar 0,990 atau $99,0 \%$ yang berarti pendapatan margin murabahah dan pendapatan bagi hasil musyarakah mempengaruhi laba bersih sebesar $99,0 \%$ sedangkan sisanya sebesar $1 \%$ dipengaruhi faktor-faktor lain yang tidak terdapat pada penelitian ini. Persamaan Regresi Berganda. Analisis regresi berganda digunakan untuk menguji pengaruh variabel independen yaitu pendapatan margin murabahah dan pendapatan bagi hasil musyarakah terhadap laba bersih. Estimasi model regresi linier berganda ini menggunakan software SPSS 250 dan diperoleh hasil output sebagai berikut: 
DOI: http://dx.doi.org/10.35137/jabk.v6i3.324

Tabel 4. Analisis Regeresi Berganda Coefficients(a)

\begin{tabular}{|c|c|c|c|c|c|}
\hline \multirow[t]{2}{*}{ Model } & \multicolumn{2}{|c|}{$\begin{array}{l}\text { Unstandardize } \\
\text { d Coefficients }\end{array}$} & \multirow{2}{*}{$\begin{array}{l}\text { Standardiz } \\
\text { ed } \\
\text { Coefficien } \\
\text { ts } \\
\text { Beta }\end{array}$} & \multirow[b]{2}{*}{$\mathrm{T}$} & \multirow[b]{2}{*}{ Sig } \\
\hline & B & $\begin{array}{l}\text { Std. } \\
\text { Error }\end{array}$ & & & \\
\hline 1 (Constant & $\begin{array}{l}305.6 \\
51\end{array}$ & $\begin{array}{l}928.4 \\
76\end{array}$ & & .329 & $\begin{array}{l}.75 \\
9\end{array}$ \\
\hline $\begin{array}{l}\text { Pendapata } \\
\text { n Margin } \\
\text { Murabaha } \\
\text { h }\end{array}$ & .455 & .103 & .383 & $\begin{array}{l}4.43 \\
2\end{array}$ & $\begin{array}{l}.01 \\
1\end{array}$ \\
\hline $\begin{array}{l}\text { Pendaptan } \\
\text { Bagi } \\
\text { Hasil } \\
\text { Musyarak } \\
\text { ah }\end{array}$ & .524 & .069 & .657 & $\begin{array}{l}7.60 \\
6\end{array}$ & $\begin{array}{l}.00 \\
2\end{array}$ \\
\hline
\end{tabular}

a Dependent Variable: Laba Bersih

Sumber : Data analisis statistik

Hasil analisis data berdasarkan perhitungan data olahan diperoleh persamaan regresi berganda sebagai berikut:

$\mathbf{Y}=\mathbf{a}+\mathbf{b}_{1} \mathbf{X}_{1}+\mathbf{b}_{2} \mathbf{X}_{2}$

$Y=305.651+0,455 X_{1}+0,524 X_{2}$

Dimana :

$\mathrm{Y}=$ Laba Bersih

$\mathrm{X}_{1}=$ Pendapatan Margin Murabahah dan $\mathrm{X}_{2}$ $=$ Pendapatan Bagi Hasil Musyarakah

Koefisien yang terdapat pada persamaan di atas dapat dijelaskan sebagai berikut :a). Nilai konstanta (a) sebesar 305.651 rupiah menyatakan bahwa jika pendapatan margin murabahah dan pendapatan bagi hasil musyarakah nilainya adalah 0 maka laba bersih nilainya positif yaitu 305.651 . b). Nilai koefisien regresi variabel pendapatan margin murabahahbernilai positif 0,455 . Hubungan positif antara margin murabahah dengan laba bersih, semakin tinggi margin murabahah maka semakin meningkat pula laba bersih. Artinya setiap peningkatan pendapatan margin murabahah sebesar Rp.1 maka akan menaikkan laba bersih sebesar Rp. 0,455. c).Pendapatan bagi hasil musyarakah memiliki koefisien bertanda positif sebesar 0,524. Hubungan positif antara pendapatan bagi hasil musyarakah dengan laba bersih, semakin tinggi pendapatan bagi hasil musyarakah maka semakin meningkat pula laba bersih. Artinya setiap peningkatan pendapatan bagi hasil musyarakahsebesar Rp.1 maka akan menaikan laba bersih sebesar Rp. 0,524.

\section{KESIMPULAN}

Dari hasil analisis dan pembahasan, maka dapat ditarik kesimpulan sebagai berikut :1). Nilai koefisien korelasi antara pendapatan margin murabahah dengan laba bersih sebesar 0,920 dengan arah positif. Hal ini menunjukkan bahwa pendapatan margin murabahah dengan laba bersih menunjukkan hubungan yang sangat kuat karena berada diantara $0,80-1,000$ yang berarti pendapatan margin murabahah sangat kuat dalam meningkatkan laba bersih. 2). Nilai koefisien korelasi antara pendapatan bagi hasil musyarakahdengan laba bersih sebesar 0,970 dengan arah positif. Hal ini menunjukkan bahwa pendapatan bagi hasil musyarakah dengan laba bersih menunjukkan hubungan yang sangat kuat karena berada diantara $0,80-$ 1,000 yang berarti apabila pendapatan bagi hasil musyarakah meningkat maka laba bersih juga meningkat begitu sebaliknya. 3). Pada posisi hubungan antara pendapatan margin murabahah dan pendapatan bagi hasil musyarakah terhadap laba bersih secara simultan atau bersama-sama, maka dapat dilihat dari tabel koefisien korelasi sebesar 0,995 yang artinya hubungan antara pembiayaan pendapatan margin murabahah dan pendapatan bagi hasil musyarakah terhadap laba bersih secara bersama-sama menunjukan hubungan yang sangat kuat karena beradadiantara $0,80-1,000$ yang berarti apabila pendapatan margin murabahah dan pendapatan bagi hasil musyarakah meningkat maka laba bersih juga meningkat begitu pula sebaliknya.

\section{DAFTAR PUSTAKA}

Abusharbeh, M, 2014, Credit Risks and Profitability of Islamic Banks: Evidence from Indonesia. Journals of Business and Economic

Agza dan Darwanto, 2017, Pengaruh Pembiayaan Murabahah, Musyarakah, dan Biaya Transaksi terhadap Profitabilitas Bank Pembiayaan Rakyat Syariah.Jurnal Kajian Ekonomi dan Bisnis Islam, Vol 1, No 1

Almunawaroh.,2017, Analisis Pengaruh Pembiayaan Musyarakah terhadap 
DOI: http://dx.doi.org/10.35137/jabk.v6i3.324

Profitabilitas Bank Syariah di Indonesia ,JurnalAkuntansi, Vol 12, No 2

Anjarsari, Kiki Yunita, 2017, Pengaruh Simpanan Dana Pihak Ketiga (DPK), Pendapatan Margin, Pembiayaan Murabahah (Studi Kasus pada Bank Mandiri Syariah dan Bank Mega Syariah), JurusanKeuangan Islam, Fakultas Syariah dan Hukum Universitas Islam Negri Sunan Kalijaga Yogyakarta

Antonio, Muhammad Syafii, 2016, Bank Syariah Dari Teori ke Praktek, Jakarta: GemaInsani

Fadhila, N, 2015, Analisis Pembiayaan Mudharabah dan Murabahah terhadap Laba Bank Syariah Mandiri: Jurnal Riset Akuntansi dan Bisnis, Vol 15, No 1

Gemina\&Supriyadi, 2018, The Effect of Murabahah, Mudharabah and Ijarah Earnings Upon the Profit of Bank BRI Syariah, Branch Office Sukabumi: The Management Journal of Binaniaga, vol 3, no. 7

IkatanAkuntansi Indonesia (IAI). 2014, Pernyataan StandarAkuntansi (PSAK) No 23 Tentang Pendapatan, Jakarta: IAI

IkatanAkuntansi Indonesia (IAI). 2009, Pernyataan StandarAkuntansi (PSAK) No 2 Tentang Laporan Arus Kas, Paragraph 04, Jakarta: IAI

IkatanAkuntansi Indonesia

(IAI). 2007,Pernyataan Standar Akuntansi (PSAK) No 106 Tentang Akuntansi Musyarakah, Jakarta: IAI

Ismail. 2011, Perbankan Syariah, Jakarta: KencanaPrenada Media Group

Karim, Adiwarman A, 2016, Bank Islam: Analisis Fiqh dan Keuangan, Jakarta: Rajawali Pers

Kasmir. 2011, Analisis Laporan Keuangan, Jakarta: Raja GrafindoPersada

Kasmir, 2016, Bank dan Lembaga Keuangan Lainnya, Jakarta: Rajawali Pers

Maryam, 2012,Pengaruh Pendapatan Margin Murabahah dan Pendapatan Bagi Hasil Musyarakah terhadap Laba Bersih perusahaan pada PT Bank Muamalat Indonesia, Tbk 2007 - 2011. Jakarta: Skripsi UniversitasKrisnadwipayana
Mujahidin, Akhmad, 2016, Hukum Perbankan Syariah, Jakarta: PT Raja Grafindo Persada

Mustofa, Imam, 2016, Fikih Muamalah Kontemporer, Jakarta: Raja Grafindo Persada

Pedoman Akuntansi Perbankan Syariah Indonesia (PAPSI). 2013. Bank Indonesia

Permata, Yaningwati dan Zahroh, 2014, Analisis Pengaruh Pembiayaan Mudharabah dan Musyarakah terhadap Tingkat Profitabilitas (ROE), Jurnal Administrasi Bisnis, Vol 12, No 1

Sa'adah, Susyanti dan Wahono., 2017, Pengaruh Pembiayaan Berakad Mudharabah, Musyarakah, dan Murabahah terhadap Profitabilitas (Studi Kasus pada Bank Umum Syariah di Indonesia Tahun 20112017), JurnalRisetManajemen

Samryn, L. M, 2012, Akuntansi Manajemen Informasi Biaya untuk Mengendalikan Aktivitas Operasi dan Investasi, Edisi Pertama, Jakarta: Kencana Prenada Media Group

Sari dan Syafitri., 2012, Pengaruh Pembiayaan Murabahah dan Tingkat Suku Bunga Bank Indonesia terhadap Pendapatan Margin Murabahah pada PT Bank Syariah Mandiri, Jurnal Ilmiah STIE $M D P$, Vol 2 No 1

Sofyan Safri, Harahap, 2011, Teori Akuntansi, Edisi Revisi 2011, Jakarta :Rajawali Pers

Sri Nurhayati, Wasilah. 2012, Akuntansi Syariah di Indonesia, Edisi 4, Jakarta: Salemba Empat

Sudarsono, Heri. 2012, Bank dan Lembaga Keuangan Syariah; Depenelitian dan Ilustrasi, Yogyakarta: Ekosoria

Undang-Undang No. 21 Tahun 2008, Tentang Perbankan Syariah, Pasal 1ayat 7

Walter T, Charles T, C. William and Themin S. 2012, Akuntansi Keuangan, Edisi IFRS, Edisi 8, Jilid 1, Jakarta: Erlangga

Wiroso. 2011, Akuntansi Transaksi Syariah, Jakarta: IAI

Wowor dan Mangantar, 2014, Laba Bersih dan Tingkat Risiko Harga Saham Pengaruhnya terhadap Dividen pada 
DOI: http://dx.doi.org/10.35137/jabk.v6i3.324

Perusahaan Otomotif yang Terdaftar

di BEI, Jurnal EMBA, Vol 2, No 4.

Yaya, Rizal, 2016, Akuntansi Perbankan

Syariah Teori dan Praktik

Kontemporer, Cetakan 2, Jakarta :

Salemba 
ISSN : 2406-7415

e-ISSN : 2655-9919

JURNAL AKUNTANSI DAN BISNIS KRISNADWIPAYANA Vol. 6 No. 3 (September - Desember) 2019

DOI: http://dx.doi.org/10.35137/jabk.v6i3.324 